\title{
Electrochemical Determination of Mangiferin Using Modified Screen Printed Electrode
}

\author{
Somayeh Tajik ${ }^{1, *}$, Niloufar Akbarzadeh-Torbati ${ }^{2, *}$, Mohadeseh Safaei ${ }^{3}$, Hadi Beitollahi ${ }^{1,3}$ \\ ${ }^{1}$ NanoBioElectrochemistry Research Center, Bam University of Medical Sciences, Bam, Iran \\ ${ }^{2}$ Department of Chemistry, University of Sistan and Baluchestan, P.O. Box 98135-674, Zahedan, Iran \\ ${ }^{3}$ Environment Department, Institute of Science and High Technology and Environmental \\ Sciences, Graduate University of Advanced Technology, Kerman, Iran \\ *E-mail: tajik_s1365@yahoo.com, n.akbarzadeh@chem.usb.ac.ir
}

doi: $10.20964 / 2019.05 .51$

Received: 4 January 2019/ Accepted: 14 March 2019 / Published: 10 April 2019

In this research, the utilization of $\mathrm{ZnFe}_{2} \mathrm{O}_{4}$ nanoparticles modified screen printed electrode $\left(\mathrm{ZnFe}_{2} \mathrm{O}_{4}\right.$ /SPE) was focused on as a sensor to determine mangiferin. The modified electrode performance was examined via the differential pulse and cyclic voltammetric methods. Mangiferin electrochemical behavior in phosphate solution of $\mathrm{pH} 7.0$ was assessed by utilizing unmodified $\mathrm{SPE}$ and $\mathrm{ZnFe}_{2} \mathrm{O}_{4} / \mathrm{SPE}$. Results indicated that $\mathrm{ZnFe}_{2} \mathrm{O}_{4} / \mathrm{SPE}$ electrochemical response to mangiferin was considerably advanced. Linear responses were exhibited by $\mathrm{ZnFe}_{2} \mathrm{O}_{4} / \mathrm{SPE}$ in mangiferin electrochemical oxidation within concentration range 0.1-600.0 $\mu \mathrm{M}$. The $\mathrm{ZnFe}_{2} \mathrm{O}_{4} / \mathrm{SPE}$ sensor exhibited suitable response for mangiferin with $0.03 \mu \mathrm{M}(\mathrm{S} / \mathrm{N}=3)$ detection limit. $\mathrm{ZnFe}_{2} \mathrm{O}_{4} / \mathrm{SPE}$ analytical application was tested with favorable results in determining mangiferin in real samples.

Keywords: Mangiferin, Voltammetry, Modified electrode, antioxidants, $\mathrm{ZnFe}_{2} \mathrm{O}_{4}$ nanoparticles

\section{$\underline{\text { FULL TEXT }}$}

(C) 2019 The Authors. Published by ESG (www.electrochemsci.org). This article is an open access article distributed under the terms and conditions of the Creative Commons Attribution license (http://creativecommons.org/licenses/by/4.0/). 